\title{
Pactários \\ uma história do Brasil
}

\author{
DEALERS WITH THE DEVIL \\ A history of Brazil
}

\section{Regina Zilberman}

Universidade Federal do Rio Grande do Sul - UFRGS - Porto Alegre - Brasil

\begin{abstract}
Resumo: O mito de Fausto narra o pacto de um indivíduo com o demônio, a quem vende a alma em troca de poder, riqueza e juventude. A concretização do pacto depende do crédito na existência do demônio, entidade que se manifesta tardiamente na Antiguidade, mas que se torna parte do pensamento cristão a partir da Idade Média. O mito de Fausto expande-se durante o período renascentista e depois, consolidando a personagem "pactária" enquanto patrimônio da literatura ocidental, de que são exemplo as obras "A Salamanca do Jarau", de João Simões Lopes Neto, "A teiniaguá", episódio de O Continente, de Erico Verissimo, e Grande sertão: veredas, de João Guimarães Rosa.
\end{abstract}

Palavras-chave: Pacto; Demônio; Fausto; Simões Lopes Neto; Erico Verissimo; Guimarães Rosa.

Abstract: The myth of Faust narrates the pact ou deal of a human being with the devil, to whom he sells the soul in exchange for power, wealth and youth. The fulfillment of the pact depends on the belief in the existence of the devil, an entity that manifests itself late in Antiquity, but becomes part of Christian thought since the Middle Ages. The myth of Fausto expands during the Renaissance period and later, consolidating the "covenanter" as a patrimony of the Western literature. Exemples are "A Salamanca do Jarau", by João Simões Lopes Neto, "A teiniaguá", episode from O Continente, by Erico Verissimo, and Grande sertão: veredas, by João Guimarães Rosa.

Keywords: Pact; Devil; Faust; Simões Lopes Neto; Erico Verissimo; Guimarães Rosa. 
o senhor acredita, acha fio de verdade nessa parlanda, de com o demônio se poder tratar pacto? Riobaldo, em Grande sertão: veredas

\section{Pactos, demônios e Faustos}

Todo pacto resulta de um acordo, cujas regras são evidentes para os que ajustam seus termos, as (pelo menos) duas partes em princípio em condições de igualdade, no sentido de cada uma delas ter algo a oferecer, pelo qual receberá algum bem em troca. É, pois, uma modalidade de negócio, mas, como não prescinde de um acerto, conta com normas, mesmo quando acatadas apenas por quem celebra o trato.

Pactos são realizados no plano político, econômico ou social. Seu conteúdo supõe várias alternativas, mas poucas são tão expressivas como a que justapõe um ser humano, mortal e limitado, e uma divindade, imortal e dotada de poderes extraordinários. Na Bíbilia hebraica, pactos desse teor fundam a religião judaica, quando Deus poupa a vida de Isaac, filho de Abraão, que provara sua lealdade a Jeová, cujo culto doravante lidera.

Pactos com o antagonista de Deus, o demônio, aparecem posteriormente na cultura ocidental. Coube primeiramente conferir forma e personalidade ao diabo enquanto personagem da mitologia cristã, o que tomou alguns séculos. Na Bíblia hebraica, é uma presença tardia, não se confundindo com a serpente que, no Gênesis, induz Eva a se apropriar do fruto da árvore do conhecimento: "ao longo de toda a passagem não há a mais leve, a mais remota referência a qualquer força sobre-humana que houvesse intervindo na tentação. A tentação é obra da serpente" (PIMENTA, 1965, p. 233).

Satanás inaugura sua participação na Bíblia com o Livro de Jó. Contudo, como observa Alberto Pimenta, "não é um diabo que aqui nos surge do nada e pela primeira vez: é um Satanás, quer dizer, um 'opositor'. No Livro de Jó, Satanás aparece como anjo entre outros anjos, aparece na corte do Senhor, não um renegado (não havia motivo para isso), mas um conselheiro com missão especial: a de observar e criticar. Jeová não o expulsa nem sequer o repreende pela sua crítica: opõe-se-Ihe por sua vez" (PIMENTA, p. 233). Segundo Édouard Langton, "é difícil considerar Satanás como pertencendo à esfera da demonologia". Na Bíblia hebraica, ele aparece não só no Livro de Jó, mas também no Livro de Zacarias e em I Crônicas, textos elaborados entre 519 e 300 a. C., aproximadamente, sendo que "o nome deriva de uma raiz sâtan, significando 'opor-se, comportar-se como adversário'" (LANGTON, 1951, p. 62).

Contudo, é ainda na Antiguidade que Satanás passa de "acusador" ou "adversário" a responsável pela queda do homem e perda do Éden. Duas obras apócrifas, mas bastante populares, narram o processo: o Livro de Enoch, em que "toda a história da tentação de Eva, tal como a conhecemos, surge aí pela primeira vez"' (PIMENTA, p. 238. Grifo do A.); e a Vida de Adão e Eva, provavelmente de 100-80 a. C., relativa à expulsão do anjo rebelde (posteriormente denominado Lúcifer) e à tentação de Eva pelo diabo: aqui, "os nomes de Satanás e do Diabo são intercambiáveis, e o caráter de Satanás, inimigo de Deus e dos homens, se encontra mais plenamente desenvolvido que no Novo Testamento" (LANGTON, p. 174). Mircea Eliade observa que "agora, Satanás encarna o princípio do Mal; torna-se o Adversário de Deus" (ELIADE, 1979, t. I, v. 2, p. 34. Grifo do A.).

Às menções esporádicas a Satanás ou à sua participação em livros apócrifos, que assinalam de certo modo a marginalidade tanto da personagem, quanto dos temas da tentação e da queda, opõe-se a centralidade que o demônio passa a deter a partir da Idade Média. Harold Bloom indica o papel decisivo desempenhado por Santo Agostinho: "a verdadeira dívida do Demônio é com Santo Agostinho" (BLOOM, 1996. p. 54):

É na Cidade de Deus que ficamos sabendo da história central da rebelião de Satanás, provocada pelo orgulho, e que precede a 
criação de Adão, de modo que a sedução de Adão e Eva por ele vem depois da queda dos anjos. (BLOOM, p. 55).

Isidoro de Sevilha, no século VI, confirma as características dos demônios, referindo-se à sua origem - anjos "caídos" -, e ao lugar onde habitam: "certos espaços aéreos", não "os mais puros do ar, mas à parte tenebrosa, que é ao mesmo tempo para eles como um cárcere até o dia do juízo". Chama-os de "anjos prevaricadores", "cujo príncipe é o diabo". Este nome dá conta de sua natureza, pois, conforme Isidoro de Sevilha, "Diabo em hebraico significa o que cai para abaixo, porque desprezou estar no cume do céu e pelo peso da soberba caiu ao abismo" (ISIDORO DE SEVILHA, 1951, p. 203).

Denominações variadas, como Lúcifer, Mefistófeles e Belzebu, entre outras, se agregam à figura do diabo ou Satanás. A partir do século XIV, passa a dispor de representação textual, como na Comédia, de Dante Alighieri, e visual, como no Juízo final, de Giotto. Seu reino deixa de ser os "espaços aéreos" a que se refere Isidoro de Sevilha, e sim, conforme Dante, o gelado mundo subterrâneo, o inferno, de onde administra o império do mal.

A afirmação da existência do demônio e a difusão de seus malefícios por meio de imagens visuais confirmavam a presença da malignidade, ausente na Bíblia Hebraica e pouco relevante nos Evangelhos. O mal, porém, vicejava e cabia conferirIhe fisionomia, mesmo que aterradora e indesejada, papel que o diabo ocupa de modo crescente no imaginário e nas práticas medievais.

O Renascimento não obscureceu a figura do Diabo: "a emergência da modernidade em nossa Europa ocidental foi acompanhada de um inacreditável medo do diabo. A Renascença herdava seguramente conceitos e imagens demoníacos que se haviam definido e multiplicado no decorrer da Idade Média" (DELUMEAU, 1990, p. 239). satanismo igualmente gozou de grande popularidade: "calculou-se que entre as primeiras edições e as reimpressões, um mínimo de 231600 exemplares de obras relativas ao mundo demoníaco foi lançado no mercado alemão na segunda metade do século XVI, do qual cerca de 100 mil na década de 1560 e 63 mil na década de 1580" (DELUMEAU, p. 246).

"O medo do diabo", sobretudo entre 1575 e 1625, não se restringiu apenas às classes populares, mas "tomou sobretudo os meios dirigentes do qual saíam teólogos, juristas, escritores e soberanos" (DELUMEAU, p. 248). Não surpreende que, neste contexto, tenha aparecido e se popularizado a narrativa que expressa de modo cabal as relações entre o ser humano e o demônio: o mito de Fausto, personagem cuja origem remontaria à Antiguidade. Eliade refere-se a Simão o Mágico, "o primeiro herético e o pai de todas as heresias", adorado como "primeiro Deus", ao lado de sua companheira, Helena: "a lembrança desse casal excêntrico, ao que tudo indica, deu origem à lenda de Fausto, o arquétipo do mágico. Com efeito, Simão era conhecido em Roma como Faustus ('o Favorecido') e a sua companheira foi, numa existência anterior, Helena de Troia" (ELIADE, p. 144). Hans Mayer confirma a associação: "Já na Antiguidade e no começo do período cristão corriam histórias de Simão o Mago, que viveu em concubinato com a bela Helena de Troia" (MAYER, 1979. p. 10). Santo Agostinho, nas Confissões, recorda "o bispo dos maniqueístas, chamado Fausto, grande laço do demônio pois seduzia a muitos por meio da sua melíflua eloquência" (AGOSTINHO, 2010, p. 68).

A partir do século $X V$, lenda e história se misturam, espalhando o renome de Fausto pela Europa. O precursor histórico teria sido Johannes Georg Faust ou Faustus, nascido em torno a 1480 em Knittlingen, na região de Würtenberg, teólogo e nigromante (cf. WATT, 1999; cf. HOLANDA, 1996); mas é o Livro de Fausto que difunde o prestígio do mago e sua arte. Publicado em 1587 por Johann Spiess, apresenta os principais eventos relativos à trajetória do protagonista: prática da magia negra, venda da alma ao diabo em troca de poder, riqueza e juventude, assinatura do contrato com sangue e gozo da companhia de mulheres sedutoras, destacandose, dentre elas, Helena de Troia. O sucesso do livro, que "suscitou umas 24 edições nos doze últimos anos do século" (DELUMEAU, p. 246), relaciona-se à 
expansão da imprensa, "sobretudo na Alemanha, e em especial como resultado das obras de Lutero, [onde] se produziu fenomenal incremento de obras didáticas e populares, ao mesmo tempo em que aumentou o público das mesmas" (WATT, p. 35).

A associação com a difusão do livro impresso não é ocasional, pois Fausto - histórico ou lendário foi confundido com Johan Fust, o banqueiro que ajudou financeiramente Gutenberg, mas que depois o processou por não pagar a dívida, apropriando-se de sua tipografia e incrementando a própria fortuna (cf. MAN, 2004, p. 169; p. 189). Em uma época em que a imprensa era entendida enquanto simultaneamente "arte divina" e "máquina infernal" (EISENSTEIN, 2011, p. 107), não surpreende que um editor, sobretudo quando pragmático e interesseiro, fosse visto como demoníaco e transgressor.

A história do mago pactário, opondo o Bem e o Mal, a tentação e a virtude, tinha muito a oferecer à visão de mundo dualista que caracteriza a dramaturgia do período elisa-betano, e não por acaso Christopher Marlowe, em A trágica história do Dr. Fausto (MARLOWE, 1977), de 1592, produz a primeira encenação do mito. Mas é também durante o lluminismo que a lenda se difunde, interessando Lessing e, depois, Goethe, o qual consumiu boa parte de sua vida redigindo e aperfeiçoando seu Fausto. No século XIX, o tema é retomado por $A$. von Chamisso, em 1803, A. Pushkin, em 1826, Christian Dietrich Grabbe, em 1829, Charles Gounod, em 1859. Sucederam-no, no século XX, Fernando Pessoa (Fausto: tragédia subjetiva, inacabada), Paul Valéry (Mon Faust, de 1945) e Thomas Mann (Dr. Faust, de 1947), o que aponta para a longevidade e resiliência do mito.

\section{Faustos no Brasil}

Ian Watt considera a história de Fausto um dos mitos da individualidade moderna, ao lado dos de D. Juan, D. Quixote e Robinson Crusoe. Com efeito, o aparecimento deles ocorre entre os séculos $\mathrm{XV}$ (Fausto) e XVIII (Crusoe), datando a criação de D. Juan (O burlador de Sevilha) do século XVI, a de D.
Quixote, do XVII. Fausto é, cronologicamente, a personagem mais antiga, podendo remontar aos inícios do Cristianismo, a se acompanhar a sugestão de Mircea Eliade de que Simão o Mágico é seu precursor. A ancestralidade do Fausto depende de outro fator temporalmente distante da modernidade renascentista: o aparecimento do demônio, que também data da Antiguidade, ainda que tenha se expandido e consolidado ao longo da Idade Média, com pleno reconhecimento depois do século XIV, na aurora do Renascimento italiano.

O mito fáustico depende da crença no demônio, sem o que não existe a hipótese do pacto contrato verbal que se materializa na assinatura de um documento, à época da difusão da escrita e das artes tipográficas. É uma entidade dos novos tempos inaugurados com as navegações do século $\mathrm{XV}$, a emergência do capitalismo mercantil, as disputas religiosas que conduziram à Reforma e à Contra Reforma; mas, como carrega também elementos arcaizantes, mostra-se simultaneamente moderno e antiquado, progressista e conservador, sendo, pois, intrinsecamente contraditório. Não por outra razão sua história pode servir a objetivos doutrinários enquanto "literatura protestante de advertência", como os que Hans Mayer (p. 21) reconhece na obra de Spiess; mas também pode revelar intuitos libertários e humanistas, de que é expressão a obraprima de Goethe. De todo modo, Fausto perenizou-se na literatura, não deixando de migrar para narrativas brasileiras desde o século XIX.

Para identificar sua presença, elementos básicos se fazem necessários. O primeiro deles é a participação de uma personagem dotada de algum tipo de ambição ou carência, a ser superada com ajuda de poderes mágicos. Esse ponto de partida é encontrado em narrativas populares, como os contos de fadas, mas, no caso da situação fáustica, a cooperação provirá de uma entidade negativa - um demônio, e não uma fada. O auxílio não é gratuito, nem espontâneo, mas tem um preço, o bem a ser recebido pelo adjuvante mágico, podendo ser a alma, a liberdade ou a vida de pessoa amada; tem também 
um prazo, ao final do que o credor cobra a dívida, um empréstimo com data marcada para pagamento.

Todos ou quase todos esses elementos aparecem em narrativas brasileiras, desenhando a trajetória dos pactários da nossa literatura. Suzi Frankl Sperber (cf. 1992) identifica em A luneta mágica, de Joaquim Manuel de Macedo, a obra que, no contexto da cultura letrada, inauguraria a temática fáustica na prosa de ficção nacional. Machado de Assis não deixou passar a oportunidade de incluí-la em sua obra, ainda que não the conferisse centralidade. "A igreja do diabo", conto publicado em 1883 na Gazeta de Notícias e, em 1884, em Histórias sem data, narra o empenho da personagem do título em criar uma seita, habilitada a acolher, em suas hostes, "todos os Faustos do século e dos séculos" (ASSIS, 1959, p. 11). Em Memorial de Aires, Fausto é uma presença explícita, quando a personagem do título aposta com a irmã, Rita, o futuro de Fidélia, a jovem viúva que, embora tivesse perdido recentemente um marido muito amado, não deixaria de, em breve, voltar a casar. Para garantir a associação com o ponto de partida do drama de Goethe, Aires localiza o livro em uma estante de sua sala e relembra: "tirei o volume do Fausto, abri a página do prólogo no céu, e li-Iha, resumindo como pude. Rita escutou atenta o desafio de Deus e do Diabo, a propósito do velho Fausto, o servo do Senhor, e da perda infalível que faria dele o astuto" (ASSIS, 1959, p. 17). Fausto é ainda presença implícita no romance, pois o narrador, idoso e também viúvo, é igualmente o objeto da aposta, ao se deixar seduzir pela beleza e graça de Fidélia, almejando dispor de condições para conquistá-la e só não chegando à perdição por não ter levado às últimas consequências os atos decorrentes de seu desejo.

Nessas narrativas, o mito de Fausto expõe duas de suas facetas: a primeira diz respeito às ações do demônio, antagonista e ao mesmo tempo interlocutor de Deus, que ambiciona povoar suas hostes com pecadores inverterados; a segunda evidencia uma das molas propulsoras do pacto - a libido, mesmo quando encoberta pela idade, que, por essa razão, é reprimida pelas expectativas da sociedade e simultaneamente intensificada na intimidade do sujeito. Fausto e, tal como ele, Aires ambicionam o que não podem possuir, sendo a mulher a representação mais evidente da interdição imposta ao desejo sexual.

"A Salamanca do Jarau", lenda datada do período das Missões jesuíticas e transcrita por João Simões Lopes Neto, acompanha a vertente do mito caracterizada pela associação motivada pelo desejo sexual, que leva à aceitação do pacto com o demônio - ou Anhangá-Pitã, na versão indígena.

A narrativa faz parte das Lendas do Sul, compiladas em livro de 1913, tendo o autor, para sua composição, baseado-se principalmente nas anotações de Daniel Granada, de onde, segundo Augusto Meyer, extraiu "todos os elementos de que se valeu para comp[ô-la]" (MEYER, 1975, p. 235). A versão de Simões Lopes organiza-se em dois eixos, que, no livro de Granada, aparecem em capítulos distintos: o primeiro recupera a história do guardião da gruta do Jarau, saudado por Blau Nunes, que vagava pelos campos à procura do boi barroso. Interrogado, o guardião conta como chegou àquele lugar e àquela posição, remontando à expulsão dos mouros provenientes de Salamanca, na Península Ibérica, que se refugiaram na região fronteiriça entre Brasil e Uruguai. Traziam consigo, acompanhando belíssima princesa, seus tesouros; são acolhidos por Anhangá-Pitã, que enfeitiça a princesa, transformando-a em uma salamandra, a teiniaguá, e ao "condão mágico" que trazia "no regaço" (LOPES NETO, 2006, v. 1, p. 198) em preciosa pedra colocada em lugar de sua cabeça. A seguir, o guardião expõe a própria história: quando jovem e sacristão da igreja de São Tomé, situada no lado ocidental do rio Uruguai, aprisionou a teiniaguá; assenhorando-se do animal mágico, sonha com as riquezas que poderia vir a possuir: "Pelo falar do padre superior eu bem sabia que quem prendesse a teiniaguá ficava sendo o homem mais rico do mundo" (LOPES NETO, p. 204).

O sacristão, porém, é seduzido pela princesa, que the promete amor e riqueza. Descoberto e condenado à morte pelo garrote, não confessa o 
crime. No momento da execução, salva-o a conjunção das forças demoníacas e da natureza, que amedrontam as pessoas e deixam o condenado sozinho. O momento é caótico, e a ordem só se restabelece por intervenção divina; mas o sacristão, tornado guardião da salamanca, não é perdoado. A retrospectiva encerra com a confissão, pelo narrador, de que tem riqueza, mas sonha com a liberdade, possível desde que saudado com cristão. Apenas Blau, que ali chegou "sem pensar" nas promessas contidas no cerro, "me saudou [ao sacristão] como filho de Deus" (LOPES NETO, p. 212), dando o primeiro passo no sentido da salvação do casal pecador

Inicia-se o segundo eixo, preparado nos parágrafos iniciais da lenda, que dão conta do período de má sorte por que passa o tapejara Blau Nunes, de que é exemplo a causa que o levara até a entrada da gruta: campeava o boi barroso, "boi encantado, que aparecia porém nunca era encontrado por muito procurado que fosse", conforme esclarece Simões Lopes Neto em nota (p. 228). "Gaúcho pobre" (LOPES NETO, p. 195), é estimulado pelo guardião a enfrentar as provas a que se submeteria se entrasse na gruta, habilitando-se, se exitoso, às riquezas ali contidas. É bem sucedido, porém as propostas do sacristão não o interessam, confessando para si mesmo ambicionar a própria teiniaguá: "Teiniaguá encantada! Eu te queria a ti, porque tu és tudo!... És tudo o que eu não sei o que é, porém que atino que existe fora de mim, em volta de mim, superior a mim. Eu te queria a ti, teiniaguá encantada!..." (LOPES NETO, p. 219).

Como consolação, o guardião premia 0 tropeiro com uma onça de ouro que se reproduz indefinidamente. De posse da moeda mágica, Blau enriquece; é, porém, mal visto, porque seu dinheiro causa problemas aos que o recebem; todos pensam que ele "tinha parte com o diabo" (LOPES NETO, p. 225) e isolam-no. Blau Nunes decide devolver a prenda e, ao reencontrar o guardião, saúda-o por mais duas vezes, quebrando o encantamento: a princesa transforma-se em "tapuia formosa", o sacristão, em "guasca desempenado" (LOPES NETO, p. 226-
227). Ainda que outra vez pobre, Blau sente o "coração aliviado": "E agora, estava certo de que era pobre como dantes, porém que comeria em paz o seu churrasco...; e em paz o seu chimarrão, em paz a sua sesta, em paz a sua vida!..." (LOPES NETO, p. 227).

"A Salamanca do Jarau" incorpora em seu enredo os elementos próprios à narrativa fáustica: Blau Nunes experimenta uma situação de extrema carência - é pobre e perseguido pelo infortúnio; sua ambição é despertada, quando se depara com a oportunidade de ter acesso à teiniaguá, o que lhe é negado, recebendo em troca a moeda mágica. Da sua parte, o sacristão cobiça riqueza, além de satisfação sexual, o que alcança após apresar a princesa moura. As duas personagens masculinas recebem a colaboração de adjuvantes vinculados ao Mal: a teiniaguá, que domina o sacristão, é representante do "diabo vermelho" dos indígenas, que a manipula; Blau é comandado pela má-sorte, depois pelos motivos materialistas induzidos pelo guardião, por último, pelo feitiço da moeda, dinheiro maldito, como o qualificam os que o recebem como pagamento.

Por outro lado, as personagens contam com atenuantes: o sacristão substitui a ambição pelo amor; e a jovem princesa não se deixa dominar inteiramente pelo demônio, que, nas palavras do narrador, "não tomou tenência que a teiniaguá era mulher..." (LOPES NETO, p. 200), observação reiterada em mais de uma ocasião. É ela também que literalmente move céus e terra para liberar o amado por ocasião do cumprimento da sentença de morte pelo garrote. Blau Nunes, por seu turno, chega involuntariamente à gruta e, depois, arrepende-se por ter aceitado o objeto mágico que agudiza sua desgraça. O remorso colabora para a redenção do casal pecador, circunstância que igualmente abranda a condenação que poderia recair sobre o campeiro.

As personagens masculinas principais alcançam os objetos de seu desejo, mas, mesmo assim, continuam infelizes. Não se verifica, na trajetória de ambos, o processo de ascensão e queda, essa decorrente do esgotamento do prazo de gozo dos privilégios concedidos. Por isso, têm direito 
à redenção, sem ter de pedir muito por ela, deixando de depender, como no Dr. Fausto, de Christopher Marlowe, da clemência de Mefistófeles, que não abre mão do negócio realizado com o cliente.

Inserção importante é a duplicação dos pactários. No enredo original, extraído de Daniel Granada, as duas personagens estão ali presentes, com alguns dos atributos encontráveis na narrativa de Simões Lopes: o caminhante que, dirigindo-se a uma feira de gado, se perdera por causa de uma tempestade; e o "homem" que encontra junto ao cerro do Jarau, apresentando-se como "cristão, da cidade de São Tomé" (GRANADA, 2003, p. 95), ali trazido por força de um encantamento. O escritor sulino atribui a cada uma delas uma trajetória própria, mas paralela, a segunda, experimentada por Blau, reproduzindo a primeira, vivida pelo sacristão, constituída pelas etapas de tentação, aceitação do pacto, infelicidade, aspiração a uma segunda chance, redenção.

A duplicação dos contratantes não significa, porém, o fortalecimento do mito, mas seu contrário, pois, dividido entre duas figuras, o pacto se fragiliza. Enfraquece-o também a vulnerabilidade dos adversários do demônio, ou Anhangá-Pitã, representados, primeiramente, pelos sacerdotes que acompanham os árabes nos navios que os trazem para a América, a seguir, pelos jesuítas de São Tomé, que desaparecem da trama assim que o sacristão escapa da punição graças à teiniaguá. O mito não supõe a estrutura prévia do luta entre o Bem e o Mal, ou entre Deus e Satanás, que direta ou indiretamente disputam o post mortem dos seres humanos. Por essa razão, a redenção das personagens não as conduz ao Paraíso ou ao Inferno, mas para o espaço natural externo à salamanca, a "várzea limpa, plana e verde, serena e amornada de sol claro, [...] como uma cancha convidante para uma cruzada de ventura, em viagem de alegria, a caminho do repouso!..." (LOPES NETO, p. 227). Ali a "tapuia formosa" e o "guasca desempenado" conduzirão sua existência, tanto quanto Blau levará "em paz a sua vida".
Esse final confirma a fragilização do mito, pois coincide com o desencantamento do espaço e das personagens originalmente dotadas de poderes mágicos. Da sua parte, o mito de Fausto converte-se em uma narrativa de origens, pois o relato cobre pelo menos duzentos anos, transcorrendo aproximadamente entre 1650 e 1850, talvez mais se regredirmos ao tempo da expulsão dos árabes que ocupavam a Península Ibérica.

Acompanham-se, assim, fatos que se estendem desde o início da ocupação da América meridional, no século XVII, com a fundação das Missões jesuíticas, até o pleno estabelecimento da classe latifundiária e criadora de gado. Neste período, deu-se a expulsão dos padres missioneiros, a incorporação da região à colônia portuguesa, a destruição dos Sete Povos, a submissão dos indígenas, a consolidação da economia pastoril e a instalação, no poder, dos grandes proprietários de terra, hegemônicos à época em que começa a narração do texto e encerra-se a ação dessacralizadora de Blau.

A lenda não é exposta desde o ponto de vista dos sujeitos desses acontecimentos, sejam eles os jesuítas que administravam a região quando o sacristão foi seduzido pela teiniaguá, sejam os latifundiários que comandavam a política local quando Blau encontrou a gruta, com seus tesouros, e libertou as vítimas do encarceramento pelo demônio. Nas duas situações, as personagens estão submetidas aos senhores da terra, o sacristão servindo aos padres, Blau dependendo de suas habilidades como tropeiro.

Ainda que liderem a ação narrativas, as personagens precisam se conformar à situação humilde e rebaixada, com que iniciam e concluem suas respectivas aventuras. O guardião da gruta fora índio catequisado e acaba "guasca desempenado", Blau começa e termina "gaúcho pobre". A inferioridade social e étnica é reforçada ao final do mito, mas agora equivale à paz e a felicidade, conforme apontam as palavras finais da lenda.

O pacto com o diabo representa, assim, um passo em falso, porque não melhora, mas piora o 
estado das personagens; também não qualifica, mas rebaixa ou isola seus atores. Inverte-se o padrão usual das narrativas populares de aventuras, em que o protagonista pobre supera sua condição e impõe-se aos poderosos; aqui, eles retornam à situação original, apenas mais experientes e submissos, sofridos, mas adaptados.

Este conteúdo não deixa de estar presente no mito de Fausto, que, ao proceder ao pacto com o demônio e, assim, provar o fruto proibido da sabedoria, longevidade e poder, atualiza e rerritualiza o mito adâmico. Em ambos os casos, trata-se de mostrar ao homem seus limites e explicar não só porque é mister conformar-se a eles, mas contar que isso aconteceu no passado, antes de nós, ouvintes, existirmos, razão do atual estado de coisas, o que cabe igualmente aceitar.

Transferido para o contexto do Rio Grande do Sul, o sentido das narrativas originais se mantém; por isso, protagonistas e usuários pertencem aos grupos socialmente inferiorizados. É para eles que cabe contar como se originou sua condição rebaixada, afirmar que ela é imutável e sugerir que não compensa tentar alterá-la. Em outras palavras, pactos, mesmo com entidades poderosas como Anhangá-Pitã, não são suficientes, até porque aquele demônio preside o universo de uma etnia vencida, a dos indígenas.

\section{3 "A teiniaguá era mulher"}

Blau Nunes devolve a moeda encantada, porque se murmura à sua volta que "ele tinha parte com o diabo, e que o dinheiro dele era maldito porque todos com quem tratavam e recebiam das suas onças, todos entravam, ao depois, a fazer maus negócios e todos perdiam em prejuízo exatamente a quantia igual à de suas mãos recebida" (LOPES NETO, p. 225). Ao narrar os malefícios da onça de ouro, Simões Lopes confirma a versão de Daniel Granada, que informa ter o caminhante recebido uma moeda que, "embora repetidas vezes [a] gastasse, outras tantas voltou a encontrá-la no bolso de seu casaco." Acaba por se desfazer dela, porque "um fato tão singular chegou a infundir-lhe temor; e um dia jogou a onça, preferindo viver pobremente do fruto de seu trabalho" (GRANADA, p. 95).

Granada, nesse trecho, reforça o teor mágico da lenda, mas não destaca a participação da mulher, especialmente aquela que traz o carbúnculo ou pedra preciosa no lugar da cabeça e confunde-se com o demônio. Esses elementos são mencionados mais adiante e formam uma unidade, associada ao lugar, a montanha encantada, onde aparece: "Carbúnculos, anhangá-pitãs ou teiniaguás, tudo é o mesmo, todos têm uma mesma origem ou causa e representam a mesma coisa ante a imaginação do vulgo e do homem primitivo: a mãe do ouro, a força da terra, o cerro ou a montanha encantada" (GRANADA, 1959, p. 102).

Augusto Meyer reitera o vínculo entre as designações: teiniaguá, expressão utilizada na região missioneira, corresponde ao diabo vermelho ou Anhangá-Pitã, entre os indígenas, ou carbúnculo, na região andina. Em sua versão da lenda, Simões Lopes Neto reparte o que, na tradição popular, estava coeso, pois a teiniaguá resulta na metamorfose da princesa moura em salamandra, por efeito da ação de Anhangá-Pitã, de quem se distingue. Porém, não é menos diabólica, e até supera seu mentor, tendo sido capaz de enganá-lo. Intermediária do pacto, é, na mesma medida, razão da anulação do contrato, confirmando, por outro caminho, a ambiguidade de que se constitui.

A teiniaguá de Simões Lopes não se restringe aos horizontes da lenda original ou da tradução que o autor oferece em sua obra. Emprestando seu nome, ela migra para um dos sete segmentos de $O$ Continente, de Erico Verissimo, primeiro volume da trilogia O tempo e o vento. O episódio centra-se no casamento de Bolívar Cambará, filho de Bibiana e Rodrigo, e Luzia Silva. Jovem rica e culta, procedente do norte do país e educada no Rio de Janeiro, ela se transferira para Santa Fé depois de que o avô, o rico negociante Aguinaldo Silva, construíra imponente sobrado no terreno a ele hipotecado por Pedro Terra, avô materno de Bolívar. É Carl Winter, o médico que migrara da Alemanha e instalara-se na pequena cidade sulina, quem verbaliza a associação entre 
Luzia e a princesa moura, levando-o a designar a jovem pelo nome indígena da feiticeira. Ao associar a personagem mítica e a senhorita do Sobrado, o médico recapitula os componentes da lenda original, detendo-se particularmente na joia que exerce a função do carbúnculo no texto de João Simões Lopes Neto:

Winter pensou imediatamente na bela e jovem bruxa moura que o diabo, segundo a lenda que corria pela Província, transformara numa lagartixa cuja cabeça consistia numa pedra preciosa de brilho ofuscante. Como era mesmo o nome do animal? Ah! Teiniaguá! (VERISSIMO, v. 2, p. 64)

Em outro trecho, é Bibiana quem relaciona Luzia à feitiçaria, justificando a atração que o filho sente pela moça: "Às vezes chego até a acreditar em feitiço. Aquela mulher enfeitiçou ele" (VERISSIMO, p. 120). Por sua vez, a fortuna de Aguinaldo Silva, fruto de negócios escusos, teria provindo, segundo muitos, da descoberta de "uma salamanca lá para as bandas de São Borja" (VERISSIMO, p. 21). É outra vez Bibiana Terra quem denuncia a natureza demoníaca de Aguinaldo, acusando o "diabo do nortista" de "excomungado" (VERISSIMO, p. 60).

Seduzido pela moça e induzido pela mãe a recuperar a terra que outrora lhe pertencera, é Bolívar o sujeito do pacto. Particulariza a representação do pactário e do mito, de uma parte, a circunstância de a composição da personagem somar elementos da ação do sacristão e de Blau Nunes. Do primeiro, Bolívar herda a submissão ao fascínio de Luzia, de que somente se liberta quando, ao final, decide enfrentar seus inimigos políticos, morrendo no combate armado. $\mathrm{O}$ acesso à riqueza graças à união com a moça rica e logo herdeira das propriedades de Aguinaldo Silva, o que não incide em felicidade ou paz doméstica, igualmente aproxima as duas personagens. Mas é o vínculo com Blau Nunes que particulariza o desenho de Bolívar, pois aponta para o lado penoso de sua existência.

O pacto de Blau decorre da aceitação da moeda, objeto mágico que se multiplica indefinidamente, mas que é maldito, pois os beneficiários dos pagamentos feitos com ele são, a seguir, perseguidos pela má sorte. Essa moeda retorna em "A teiniaguá", quando são narrados os acontecimentos que levaram Severino, negro e escravo, a ser condenado à forca, acusado da morte de dois tropeiros. A narrativa detalha esse acontecimento.

Hospedados na chácara de um oleiro que residia nas proximidades de Santa Fé, dois homens contam ter recebido muito dinheiro graças à venda de uma tropa de mulas. Na véspera da partida, desejam remunerar o oleiro que os acolhera com "uma onça de ouro" retirada "da guaiaca recheada de moedas" (VERISSIMO, p. 29). O hospedeiro recusa o pagamento dos tropeiros que, no outro dia, são "encontrados mortos, com as cabeças esmigalhadas" (VERISSIMO, p. 29). O oleiro constata também que Severino, então seu escravo, desaparecera, concluindo que fugira. Não fora, porém, o que ocorrera: ele buscara abrigo junto a Bolívar, alegando ter sido objeto dos maus-tratos do patrão, razão por que trazia a roupa manchada de sangue. Ainda que Bolívar acredite nele, Severino evade-se; suspeito de responsável pelo homicídio, é preso e condenado à forca. A guaiaca cheia de moedas não é reencontrada.

Identificam-se no episódio que motiva a condenação de Severino elementos que remontam a "Trezentas onças", narrativa que abre os Contos gauchescos, de Simões Lopes Neto. Blau Nunes relembra a época em que, tropeiro, trazia consigo uma guaiaca contendo o produto de uma venda, as trezentas onças do título, a serem entregues ao patrão. No caminho, decide banhar-se em um riacho, retomando a seguir a viagem. Já nas proximidades da estância do patrão, percebe que esquecera a guaiaca no galho de uma árvore. Retorna ao local, mas não a localiza mais; desesperado, pensa em matar-se, pois certamente o estancieiro o acusaria de ladrão. No entanto, recua, optando por contar o que ocorrera e arcar com as consequências. Ao chegar, descobre que uma comitiva de tropeiros havia encontrado a guaiaca, entregando-a a seu dono, o que lhe dá grande alegria: "Eu também fiquei-me rindo, olhando para a guaiaca e para o guaipeva, arrolhadito aos meus pés..." (LOPES NETO, p. 51). 
Similares onças de ouro e guaiaca transitam do conto de Simões Lopes para a narrativa de Erico, mas o resultado é oposto: os tropeiros são assassinados, crime atribuído a Severino, que trazia na roupa as manchas do crime. $O$ depoimento que selara a sorte do escravo fora dado por Bolívar, testemunha da condição em que Severino chegara à sua casa e de sua fuga, após as interpelações do amigo. Mas o jovem Cambará não está convicto de que Severino cometera o homicídio para apossar-se do dinheiro, o que o deixa intranquilo, desconforto ampliado pelo fato de o enforcamento ocorrer no dia do noivado com Luzia.

Severino é, pois, personagem fundamental na construção de "A teiniaguá", permitindo a plena inserção de Blau Nunes na estrutura do texto. Como o narrador de "Trezentas onças", teve acesso à rica guaiaca; mas, talvez ao contrário daquele, deixou-se levar pela tentação, chegando ao crime. Aproxima-se, pois, do Blau Nunes de "A Salamanca do Jarau", mas não é ainda o pactário, razão talvez porque não fica evidente ter sido ele o homicida. A posição de pactário é transferida a Bolívar, atraído tanto pelo feitiço da teiniaguá, quanto pela fortuna que ela promete, herdeira do homem mais rico da cidade. Bolívar, comprometendo-se a casar com Luzia no dia em que Severino é punido, e sentindo-se, ele mesmo, o enforcado, duplica o amigo e, por efeito do procedimento de reprodução construído por Erico Verissimo, consolida sua condição de pactário.

Ao retomar a matéria e as personagens originárias de Simões Lopes, Verissimo não está sendo incoerente; pelo contrário, aprofunda as sugestões emanadas do enredo e do espaço geográfico de O tempo e o vento. "A Fonte", episódio inaugural da trajetória da família Terra Cambará, passa-se em uma das Missões guaranis, área visitada por Winter cem anos depois dos acontecimentos apresentados naquela passagem, oportunidade em que relembra: "foi na redução de São Tomé que a teiniaguá desgraçou um sacristão" (VERISSIMO, p. 97). Não por outra razão entende a personalidade de Luzia desde o paradigma da teiniaguá, expandindo os traços esboçados em "A Salamanca do Jarau".

A ampliação da figura da teiniaguá não obscurece a aceitação do pacto com o demônio por parte de Bolívar. Mas talvez reduza o peso de seu pecado, alcançando, por outro trajeto, o efeito atenuante obtido por Simões com a repartição do pactário em duas personagens em sua lenda, cada um obtendo, à sua moda, a respectiva redenção. A remissão de Bolívar resulta de outro tipo de decisão, quando prefere a morte à condenação perpétua. Em um mundo sem Deus e sem segundas oportunidades,

a decisão de Bolívar emancipa-o do pacto e consagra-o como herói libertador, fazendo jus ao nome que carrega.

\section{A teiniaguá andrógina}

É no segmento denominado "A teiniaguá" que a família Terra Cambará muda de patamar social. Ana Terra, a matriarca da família, descendia de pequenos proprietários rurais, e seu filho, Pedro, pai de Bibiana, não ultrapassara essa condição; endividado, hipotecara e perdera a casa para Aguinaldo Silva; Bibiana, viúva de Rodrigo Cambará, não tivera melhor sorte em termos econômicos. O casamento de Bolívar com Luzia não agrada à mãe do rapaz, mas ela não se opõe ao matrimônio, ciente de que, de modo indireto, recuperaria a propriedade do pai e ainda gozaria de novo status na comunidade de Santa Fé.

Somente um pacto de teor demoníaco seria capaz de sustentar a operação planejada por Bibiana, ainda que às custas do sacrifício do filho. Bolívar, porém, não é o inocente útil ou o bode expiatório: apaixonado pela moça, deixa-se guiar pelos passos da teiniaguá, a estrangeira que o seduziu e leva-o à perdição. A aproximação, por Erico Verissimo, entre o tropeiro Blau Nunes e o herói de sua narrativa matiza a composição da personagem: de uma parte, a Bolívar, entendido desde Severino, seu duplo, falta a honestidade do protagonista de "Trezentas onças"; de outra, o moço não se conforma com o negócio, que torna sua vida insuportável. Mas, na perspectiva de 
Veríssimo, o mercador demoníaco não aceita devolução, aparecendo a morte - quase um suicídio, em "A teiniaguá" - como alternativa à redenção.

Relendo Simões Lopes Neto, o autor de 0 tempo e o vento expõe uma versão menos otimista dos acontecimentos, mesmo quando atenua o pecado de Bolívar, abrandamento expresso seja pela ausência de certeza de que Severino foi efetivamente o responsável pela morte dos tropeiros, seja pela caracterização psicológica de Luzia Silva, a feiticeira que se excede no sadismo detectado por Winter e testemunhado por Bolívar em sua vida de casado. Ainda assim, Veríssimo é inflexível, não perdoando os que optam pela riqueza ou pelo poder, posicionamento que incide em uma interpretação da história do Rio Grande do Sul, matéria subjacente de sua trilogia.

É sintomático que "A teiniaguá" transcorra entre 1850 e 1855 aproximadamente, período em que conclui "A Salamanca do Jarau", de Simões Lopes, e década imediatamente posterior ao final da guerra dos Farrapos, de que resultou a definitiva integração do Rio Grande do Sul ao projeto nacional da Corte carioca. Até o término da revolução iniciada de 1835 , a região resistia à aceitação das regras centralizadoras provindas do governo. Pacificada em 1845, a Província se submete, mas, simultaneamente, desenvolve-se economicamente, somando tranquilidade militar, política e financeira. Crescem os centros urbanos, e a vida cultural se expande. O Continente do Rio Grande do Sul ingressa, enfim, na era do capitalismo, de que advirá, com o passar do tempo, a hipótese de aumentar sua participação na esfera do Estado, o que se concretiza na primeira metade do século $\mathrm{XX}$, com a tomada do poder por Getúlio Vargas.

Esse percurso histórico fundamenta a construção narrativa de $O$ tempo e o vento, ao longo de seus três volumes. "A teiniaguá" é o ponto de inflexão do processo, sendo a mudança de status dos Terra Cambará sinônimo da submissão da Província à Corte, cuja superioridade admite, e da aceitação das normas do capitalismo: o empréstimo de dinheiro resultando em lucro; a exploração da pecuária visando à exportação. Aguinaldo e Luzia Silva provêm do Norte e trazem consigo suas regras, a que se sujeitam sucessivamente Pedro Terra, ao perder a propriedade, e Bolívar, ao ceder aos caprichos da noiva. Mas o jovem Cambará, e sobretudo seus descendentes, são também beneficiários dos efeitos do pacto paterno: herdam o Sobrado e as terras do Angico, que garantem as rendas da família até o final do romance.

O mito de Fausto nasce e expande-se quando - mundo moderno dá os primeiros passos, expressando a natureza materialista das relações entre os seres humanos e as divindades. Se a existência se pauta por perdas e ganhos, o melhor é estar ao lado dos triunfantes. Erico Verissimo contabiliza, com sua teiniaguá, o preço do sucesso, não se iludindo com as aparências; pelo contrário, invade suas mentes e expõe suas falhas, seja a fragilidade do herói Bolívar, seja a violência doméstica que se instala no Sobrado construído sobre as ruínas de um passado de digna pobreza.

Que a representação do pacto na literatura brasileira acomoda-se melhor em narrativas transcorridas no meio rural, comprova-o Grande sertão: veredas, de João Guimarães Rosa, romance em que o mito de Fausto atinge seu ápice, evidenciando-se por meio de, ao menos, três personagens masculinas. O menos proeminente é o que carrega o nome de seu antecessor lendário: Faustino, "um pobre dos mais pobres" (ROSA, 1968, p. 67), com quem Davidão, "grado jagunço, bem remediado de posses" (ROSA, p. 66), fizera um trato. Segundo o combinado, Faustino é que morreria, no caso de, em combate, ter chegado a hora do Davidão. Acontece uma luta decisiva, e os dois sobrevivem. O episódio é esse; mas Riobaldo, que o expõe a seu ouvinte, o indivíduo anônimo para quem rememora sua vida, complementa que narrara a curta história "a um rapaz de cidade grande, muito inteligente" (ROSA, p. 67). Esse outro interlocutor propusera um final para a situação inconclusa: na versão imaginária, Faustino decide revogar a combinação, Davidão não aceita, os dois lutam, e o primeiro acaba morto "por sua própria mão dele" 
(ROSA, p. 67), que crava a faca no coração, falecendo.

Faustino, tal como o Fausto original, vende a vida; mas, no relato supostamente histórico de Riobaldo, o caso fica inacabado, o que o incomoda; precisa compartilhá-lo com pessoas da cidade, na busca de solução, mas essa não foge à regra, apelando ao mito original, que ensina que, se a pessoa vendeu, ela tem de entregar o produto da negociação, pois o cliente tem sempre razão.

A participação de Faustino reduz-se a poucos parágrafos, adequados a uma interpolação metalinguística. O segundo pactário, Hermógenes, ocupa a maior parte do livro, sendo seus vínculos com o demônio mencionados seguidamente tanto por Riobaldo, quanto por outros jagunços do bando de Joca Ramiro: "João Goanhá me esclareceu: - "O Hermógenes fez o pauto. É o demônio rabudo quem pune por ele..." (ROSA, p. 53). Para Lacrau, Hermógenes é "positivo pactário", sendo em nome do poder, da riqueza e do "corpo fechado" que Hermógenes "assinou a alma em pagamento" (ROSA, p. 309). Se Davidão fez um trato com Faustino para preservar a vida, Hermógenes deixou-se levar pela cobiça de terras e o gosto pela de autoridade. O desejo sexual não influencia a ação de nenhum dos dois, neutralizando o tanto de sensualidade que compõe o trato com o diabo.

À primeira vista, o universo erótico que envolve "A Salamanca do Jarau", reiterado em "A teiniaguá", esvai-se em Grande sertão: veredas. Guimarães Rosa, porém, foi leitor de Contos gauchescos e Lendas do Sul, publicado em 1949, que recebeu de Aurélio Buarque de Holanda, responsável pela edição crítica, conforme registra a dedicatória colocada na folha de rosto do livro, agora depositado da Biblioteca do Instituto de Estudos Brasileiros, da Universidade de São Paulo. O escritor pode não ter-se interessado por todos os contos, mas sublinhas e marcas nas margens, em lápis preto, nas páginas 311 e 313 do volume, sugerem que o romancista se deteve na lenda redigida por Simões Lopes Neto.

Ainda assim, Guimarães Rosa pode não ter-se deixado impactar por Simões Lopes, como ocorre com Verissimo em $O$ tempo e o vento, começando por "A teiniaguá" e estendendo-se até a parte final da trilogia. Porém, estudiosos da obra de Simões Lopes reconhecem a migração de alguns traços da poética narrativa de Simões Lopes para a escrita de Rosa, especialmente em Grande sertão: veredas (cf. BORDINI, 1973; cf. CHIAPPINI, 1988). A relevância do objeto do desejo por ocasião da realização do pacto é um dos elementos que aproximam os dois escritores, o que se verifica na ação de Riobaldo, o contratante mais credenciado do romance.

O pacto de Riobaldo pode ser repartido em três atos: no primeiro, Riobaldo dispõe-se a enfrentar Hermógenes na companhia de Diadorim: "Esse menino, e eu, é que éramos destinados para dar cabo do Filho do Demo, do Pactário!" (ROSA, p. 310). O segundo ato transcorre logo a seguir: Riobaldo decide pactuar com o diabo - "agora eu ia!" - em local prédeterminado, as Veredas Mortas. Lá chegando, confessa ao interlocutor sua principal aspiração - "E, o que era que eu queria? Ah, acho que não queria mesmo nada, de tanto que eu queria só tudo. Uma coisa, a coisa, esta coisa: eu somente queria era ficar sendo!" (ROSA, p. 318), expressão que parece repercutir o desejo de Blau Nunes diante das ofertas feitas pelo guardião da gruta, após o tropeiro ter vencido as provas colocadas em seu caminho: "Teiniaguá encantada! Eu te queria a ti, porque tu és tudo!..."

Apesar - ou talvez por causa - da autoconfiança de Riobaldo, entendendo-se "mais forte do que o Ele", de quem espera "lamber o chão e aceitar minhas ordens" (ROSA, p. 318), Lúcifer e Satanás, nomes invocados pelo narrador, não aparecem. O jagunço afasta-se das Veredas Mortas; no caminho de retorno, sente muito frio e sofre uma queda; inerme, perde a noção do tempo, vindo a jazer "mole no chato, no folhiço, feito se um morcegão caiana me tivesse chupado" (ROSA, p. 320).

A reação de Riobaldo, o frio próprio ao Inferno assim como Dante Alighieri o descreve na Comédia, a sensação de ter sido mordido por um morcego sugerem a confirmação do pacto; mas, ao chegar ao acampamento dos jagunços, o narrador nega o fato 
para si mesmo: "o enfim que nada não tinha me acontecido, e eu queria aliviar da recordação, ligeiro, o desatino daquela noite" (ROSA, p. 320). Contudo, seu comportamento altera-se radicalmente: assume a liderança do grupo, supera obstáculos antes intransponíveis, vence Ricardão, captura a mulher de Hermógenes e, enfim, depara-se com o ato final de sua trajetória - o duelo com o pactário responsável pelo assassinato de Joca Ramiro, compromisso assumido com Diadorim desde a ocorrência do crime.

Esse ato caracteriza-se pela reversão de expectativas: é Diadorim quem se apressa a matar o inimigo, morrendo também. O narrador relembra o acontecimento:

Ao ferreio, as facas, vermelhas, no embrulhável. A faca a faca, eles se cortaram até os suspensórios. ... O diabo na rua, no meio do redemunho... Assim, ah - mirei e vi - claro claramente: ai Diadorim cravar e sangrar o Hermógenes... Ah, cravou - no vão - e ressurtiu o alto esguicho de sangue: porfiou para bem matar! (ROSA, p. 450-451).

Assim narrado, o confronto entre Hermógenes e Diadorim reproduz o final da história entre Davidão e Faustino, conforme o imaginara o moço da cidade, após conhecer o episódio relatado por Riobaldo. Confirma a duplicação a circunstância de Hermógenes ser, como Davidão, um "grado jagunço, bem remediado de posses"; nesse caso, Diadorim corresponderia a Faustino, apresentando-se então como pactário.

Que Diadorim carrega traços demoníacos, sugere-o seu nome, cujas sílabas iniciais reproduzem as do diabo e que Riobaldo utiliza em uma das menções a ele: "Deus só pode as vezes manobrar com os homens é mandando por intermédio do diá?" (ROSA, p. 33. Grifo do A.). Mas seus motivos distinguem-no dos demais pactários do romance: não é pobre, como Faustino, nem ambiciona força e riqueza, como Hermógenes, pois descende de Joca Ramiro, o mais poderoso mandante da região. Também se diferencia deles por ser mulher, e é dessa condição, em um mundo dominado pelos homens, que deseja se libertar.

A renúncia à feminilidade por Diadorim é decisão tomada antes do aparecimento de Riobaldo em sua vida, pois conhece-o ainda adolescente já travestido no Menino. Depois, apresenta-se como Reinaldo, também um nome masculino, utilizado junto ao bando de jagunços liderado por Joca Ramiro. A natureza feminina de Diadorim somente se revela após sua morte, correspondendo a um desencantamento na descrição de Riobaldo:

Ela era. Tal que assim se desencantava, num encanto tão terrível; e levantei mão para me benzer - mas com ela tapei foi um soluçar, e enxuguei as lágrimas maiores. Uivei. Diadorim! Diadorim era uma mulher. Diadorim era mulher como o sol não acende a água do rio Urucuia, como eu solucei meu desespero. (ROSA, p. 454)

Diadorim, pactária na medida em que aceita a mudança de forma, camufla a natureza original, mas não inibe o poder sedutório da mulher. Compartilha, assim, a ambiguidade das teiniaguás, percepção que tem Riobaldo quando pretende presenteá-la com uma pedra, a ametista depois oferecida a Otacília, a futura esposa. Por isso, relembra também a falta da pedra por ocasião dos funerais da amada:

A Mulher lavou o corpo, que revestiu com a melhor peça de roupa que ela tirou da trouxa dela mesma. No peito, entre as mãos postas, ainda depositou o cordão com o escapulário que tinha sido meu, e um rosário, de coquinhos de ouricuri e contas de lágrimasde-nossa-senhora. Só faltou - ah! - a pedrade ametista, tanto trazida... (ROSA, p. 454)

Simões Lopes Neto acentuou o componente erótico da teiniaguá original, a salamandra coroada com o carbúnculo, a pedra brilhante, sublinhando sua identidade feminina. Desfeito o encantamento, a exprincesa moura perde os atributos mágicos, porém não se revolta, resignando-se à nova situação, a de indígena e mortal. A construção de Diadorim começa pela outra ponta: por nascimento, é mulher, mas aparentemente não se conforma com essa condição, preferindo a metamorfose em figura masculina. Alcança sucesso, porém parcial, pois converte-se em criatura dúbia, ainda que não perversa, como outra de suas antecessoras, a Luzia cujo brilho se extingue após a morte de Bolívar, restando-Ihe a moléstia que Ihe destrói o corpo.

É por não aceitar regredir à sua natureza original que a situação de Diadorim torna-se insustentável. Não há lugar para ela na sociedade que se segue à punição de Hermógenes, em que 
conceitos não toleram ambiguidade, e gêneros não admitem transitividade. Impõe-se uma visão dualista que obriga a cada um eleger o lado de cá ou o de lá, mas não os dois ou nenhum. Riobaldo experimentou, na juventude, o mundo impreciso de Diadorim, o qual continua provocar questões a que, recapitulando sua história ao interlocutor anônimo, gostaria de responder: "Viver é muito perigoso... Querer o bem com demais força, de incerto jeito, pode já estar sendo se querendo o mal, por principiar..." (ROSA, p. 16). Ele, porém, ao contrário de Diadorim, pôde concretizar a travessia, instalando-se confortavelmente em uma sociedade de classes, dividida rigidamente em grupos opostos e incomunicáveis: o dos proprietários de grandes extensões de terra, a que pertence; e o dos pobres e remediados, condenada a maioria deles a permanecer nessa posição.

A travessia, que, "A Salamanca do Jarau" é igualmente um desencantamento, não diz respeito apenas a Riobaldo, mas também à sociedade brasileira, cujas transformações, ocorridas ao longo das primeiras décadas do século $X X$, são reproduzidas no romance. Mas, ao contrário do que aparece nas obras de Simões Lopes e Erico Verissimo, a passagem na direção da modernidade faz-se de modo precário e incompleto: nem se instala em sua plenitude uma visão laica e dessacralizada de mundo, pois Riobaldo continua a reconhecer manifestações diabólicas a todo momento e, ainda que afirme, ao final, existir apenas "homem humano" (ROSA, p. 460), nada leva a crer que tenha efetivamente exorcizado seus fantasmas interiores; nem se supera o regime econômico calcado na exploração extensiva da propriedade rural e das pessoas que dependem dela.

O pacto fáustico, em sua origem, narra 0 trânsito para a modernidade: na era do capitalismo, tudo é negociável, desde que faculte a realização de aspirações íntimas, algumas até inconfessáveis. Mas, em Grande sertão: veredas, Riobaldo duvida do próprio pacto, pois a passagem fez-se de modo imperfeito, sacrificando o objeto principal de seu desejo. Da sua parte, o pacto de Diadorim, igualmente transgressor como são o das teiniaguás, também não bastou para garantir seu lugar em um meio hostil à feminilidade independente.

Eis por que o que se segue ao final, "a estória acabada" (ROSA, p. 454), não é uma nova história, mas a velha narrativa, permanentemente repisada pelo ex-jagunço. Inacabado permanece o pacto, de que depende o mundo representado - o Brasil - para Riobaldo ingressar definitivamente na modernidade. Anacrônico, o estancieiro não se liberta do passado, porque sua travessia - e nem a de Diadorim, simultaneamente mulher e homem - se completou.

\section{Referências}

AGOSTINHO, Santo, Bispo de Hipona. Confissões. Trad. J. Oliveira Santos, A. Ambrósio de Pinal. São Paulo: Folha de São Paulo, 2010.

ASSIS, Machado de. A igreja do diabo. In: Histórias sem data. São Paulo: Mérito, 1959.

ASSIS, Machado de. Memorial de Aires. São Paulo: Mérito, 1959.

BLOOM, Harold. Presságios do milênio. Anjos, sonhos e imortalidade. Trad. de Marcos Santarrita. Rio de Janeiro: Objetiva, 1996.

BORDINI, Maria da Glória. Contos gauchescos: atuação do narrador. In: BORDINI, Maria da Glória; FILIPOUSKI, Ana Mariza; NUNES, Luiz Arthur; ZILBERMAN, Regina. João Simões Lopes Neto: a invenção, o mito e a mentira. Porto Alegre: Instituto Estadual do Livro; Movimento, 1973.

CHIAPPINI, Ligia. No entretanto dos tempos. Literatura e história em João Simões Lopes Neto. São Paulo: Martins Fontes, 1988.

DELUMEAU, Jean. História do medo no Ocidente. 1300-1800. Trad. Maria Lúcia Machado e Heloísa Jahn. São Paulo: Companhia das Letras,1990.

EISENSTEIN, Elizabeth L. Divine Art, Infernal Machine. The Reception of Printing in the West from First Impressions to the Sense of an Ending. Filadélfia: University of Pennsylvania Press, 2011.

ELIADE, Mircea. História das crenças e das ideias religiosas. Trad. de Roberto Cortes de Lacerda. Rio de Janeiro: Zahar, 1979. T. I, V. 2.

GRANADA, Daniel. Reseña historico-descriptiva de antiguas y modernas superticiones del Rio de la Plata. 2. ed. Buenos Aires: Guillermo Kraft Limitada, 1959. 
GRANADA. Daniel. Reseña histórico-descriptiva de antiguas y modernas supersticiones del Río de la Plata. Montevidéu: Capibara, 2003.

HOLANDA, Sergio Buarque de. O Fausto. In: espírito e a letra. São Paulo: Companhia das Letras, 1996. V. 1. p.77-89.

ISIDORO DE SEVILHA. Etimologías. Trad. para o espanhol por Luis Cortés y Góngora. Madrid: Biblioteca de Autores Cristianos, 1951.

LANGTON, Édouard. La Démonologie. Étude de la doctrine juive et chrétienne, son origine et son développment. Paris: Payton, 1951.

LOPES NETO, João Simões. Contos gauchescos e Lendas do Sul. Org. de Aldyr García Schlee. Porto Alegre: Instituto Estadual do Livro; Unisinos, 2006.

MAN, John. A revolução de Gutenberg. Trad. Marco Antônio Oliveira. Rio de Janeiro: Ediouro, 2004.
MARLOWE, Christopher. La trágica historia del Dr. Fausto. Buenos Ayres: Xanadu, 1977.

MAYER, Hans. Höllenfahrt des Doktor Faustus. In: Doktor Faust und Don Juan. Frankfurt: Suhrkamp, 1979.

MEYER, Augusto. Guia do Folclore Gaúcho. 2. ed. rev. e aum. pelo autor. Rio de Janeiro: Presença; Brasília: Instituto Nacional do Livro; Porto Alegre: Instituto Estadual do Livro, 1975.

PIMENTA, Alberto. O conceito de diabo na Bíblia e em Gil Vicente. Separata da Revista Ocidente. V. LXIX : 231-247. Lisboa, 1965.

ROSA, João Guimarães. Grande sertão: veredas. 6. ed. Rio de Janeiro: José Olympio, 1968.

SPERBER, Suzi Frankl. O pacto: tradição e utopia. Organon. Porto Alegre: UFRGS, 6 (19) : 69- 84. 1992.

VERISSIMO, Erico. O Continente. 3. ed. São Paulo: Companhia das Letras, 2004. V. 2.

WATT, Ian. Mitos del individualismo moderno. Fausto, Don Quijote, Don Juan y Robinson Crusoe. Trad. Miguel Martínez-Lage. Madri: Cambridge University Press, 1999.

\section{COMO CITAR ESSE ARTIGO}

ZILBERMAN, Regina. Pactários uma história do Brasil. Signo, Santa Cruz do Sul, v. 42, n. 74, p. 111-125, may 2017. ISSN 1982-2014. Disponível em: <https://online.unisc.br/seer/index.php/signo/article/view/9302>. Acesso em: doi: http://dx.doi.org/10.17058/signo.v42i74.9302. 